HStud 25 (2011)1, 61-70

DOI: 10.1556/HStud.25.2011.1.5

\title{
THE IDEAS OF GYÖRGY KALMÁR
}

\author{
THEORY BEHIND HIS UNIVERSAL LANGUAGE PLAN ${ }^{1}$
}

\author{
BÉLA HEGEDÜS
}

Institute of Literary Studies, HAS

Budapest, Hungary

\begin{abstract}
This paper was written with two principal aims. The first is to offer a biographical sketch of the life of György Kalmár. The second is to present his universal language plan as a theory of language.
\end{abstract}

Keywords: György Kalmár, linguistics, universal language plan, cognition, translation, signification, hermeneutics

György Kalmár is perhaps not the best-known figure in the European history of ideas. Nevertheless, his universal language plan gained him a continental recognition in the 18th century and it still makes him a household name for the researchers of this particular subject. Recently Umberto Eco praised Kalmár's plan in his The Search for the Perfect Language:

In 1772 there appeared the project of Georg Kalmar, Praecepta grammatica atque specimina lingua philosophicae sive universalis [...], which occasioned the most significant discussion on our topic written in Italian. ${ }^{2}$

Eco then goes on to describe this discussion and not Kalmár's particular work. In fact this discussion actually was induced not by the book Eco mentions, but by its 1773 Italian edition. On the other hand, it is also highly revealing to see how Kalmár's name gets modified as he is referred to by contemporary scholars. In Hungarian his name goes as Kalmár György, that is, the second a in the surname is accentuated. He used this version of his surname in every non-Hungarian edition of his books, and always translated only his first name to other languages. Consequently the author of the book Eco referred to was not Georg Kalmar, but Georgius Kalmár. Sadly enough, the low level of his recognition even in Hungarian culture is indicated by the fact that the Hungarian translators of Eco's book failed to realize that this obscure person was he Hungarian Kalmár György, and they kept the name "Georg Kalmar", which does not make any sense. 
As an addition to this obscurity, the life of the author named György Kalmár is also full of uncertainties and strange features. ${ }^{3}$ In what follows, I will outline what we know of his life to bring this 18th century Central-East-European figure a bit closer to the reader.

At first sight a contrast appears between Kalmár as an author and as a real-life person. In Hungarian scholarship Kalmár has been traditionally considered an eccentric or even a lunatic, and definitely an alcoholic, who produced a great deal of unreadable hexameters. His most important work, the plan for an universal language was simply beyond the 18th century Hungarian intellectuals, who were, quite frankly, rather 'under-qualified' in terms of philosophy. Even Ferenc Kazinczy, an emblematic figure of 18th century Hungarian literature, admitted that he did not understand Kalmár's works at all, but he emphasized that Kalmár was known to have consumed only vinegar and grains during his Oriental travels.

In 1772 the famous Strabon-translator, Abraham Jacob Penzel of Breslau wrote a letter to the renowned philosopher-mathematician Johann Heinrich Lambert of Berlin. In the letter he described his last night visitor: a dishevelled, squalid, sick-looking man who claimed himself to be György Kalmár. Penzel knew the works of Kalmár, the famous grammarian and scholar, so he could not believe that this tramp was the author of those books, he could not be identical with Kalmár. As the tramp mentioned Lambert as his alleged patron, Penzel was eager to warn Lambert. But in his reply Lambert confirmed the unbelievable, that man must have been nobody else but Kalmár (whose book he had published the previous year in Berlin), for the description, his looks and behaviour, that is, at night he usually ended up getting drunk, fits him perfectly. ${ }^{4}$

Now, let me give a more detailed introduction of this strange and extraordinary figure. He was born in 1726 in Tapolcafö, Hungary. After his studies in Debrecen he went to Oxford in 1749, and there in the following year he published his dissertation written in Latin. In 1751 he contributed three pamphlets in English to the debate between the Hutchinsonians and Thomas Sharp. As a matter of fact, he was the only scholar who joined the debate defending Sharp. No doubt that this controversy definitely had an impact on the formation of Kalmár's language theory.

We do not know too much about Kalmár's residence in Britain or about his personal and intellectual contacts. According to his own account, he won an award with his Oxford dissertation and it covered the costs of his first great journey. Unfortunately, from this time of his life only a few letters survived, but those clearly show that he was in correspondence with scholars not only from Britain, but also from New England, like Ezra Stiles of New Haven.

In 1753 Kalmár travelled to the Netherlands, Switzerland, and in 1754 to Italy. Then he left Rome for Hungary via Vienna. Shortly after, he set off again and travelled to Constantinople via Transylvania and Bucharest. He spent seven months in the Ottoman Empire. We do not know too much about the reasons of his Mid- 
dle-East travels, in a letter he himself mentions the purpose of learning more languages.

Later he visited Egypt, where he spent one month. His next destination was Palestine, then he returned to Constantinople. During his 17-month Oriental trip he enjoyed the hospitality of British ambassadors and consuls. In general, the strange-looking, eccentric Kalmár had exceptionally and surprisingly good contacts. The subscribers of his books included aristocrats, ambassadors, ministers, even Catholic bishops.

From Constantinople now he left for Russia via Moldavia. He spent half a year there and in 1757 he came home via Poland. The fact that he was offered the chair of the Hebrew department at the university of Saint Petersburg indicates the reputation he must have gained by that time. Nevertheless, he declined the offer, claiming that he wished to return to Hungary and pursue his activities there.

In the meantime, the books he had obtained in England got stuck in Belgium. Being eager to get them back, in 1759 he travelled to Switzerland, where he had his Hebrew grammar published in Latin. Then he moved on to Copenhagen via Strasbourg. The details of the subsequent legs of his second European trip are difficult to follow: what we know is that he definitely visited Königsberg, ${ }^{5}$ Halle, Leipzig, Breslau, Warsaw, and he also appeared in Iași, Moldavia and Transylvania.

The books he had bought in Britain were finally delivered to Hungary in 1762, but the censorial office confiscated them at the border. As a lucky consequence, at least we have a list of his books. We also do know of his next trip in 1767, when he appeared in Jena, and in the same year in Halle he had his Hebrew grammar published in Ancient Greek. This work is one of the two of the kind ever made. He carried 200 copies to Saint Petersburg, where Gabriel metropolite offered him again the chair of the Hebrew department. Kalmár rejected the offer again.

By this time he certainly had contacts with some of the most significant scholars of the age (e.g., Lomonosow, Johan Georg Hamann, Breitinger, Beck, Hagenbuch, van Swieten, etc.). However, what gained him a really widespread recognition was his universal language plan. First it was published in Berlin and Leipzig in 1772, it was sponsored by Johann Heinrich Lambert, and one of the few subscribers was Moses Mendelssohn. The work also appeared in Italian translation in Rome and a year later in German in Vienna.

In these years, a disciplinary procedure was initiated against him by the Calvinistic Church. In the course of the procedure Kalmár's pietist conversion was recorded in several documents. From the 1770s onwards fewer references can be found, most of them mocking his personality. By 1781 he had disappeared completely, both the date and the place of his death are yet to be found out.

The most detailed presentation of Kalmár's language theory can be found in his universal language plan. However, we can distinguish no less than three versions. 
The first one, as I have mentioned, was published in Latin in Berlin in 1772. To the Italian version, published in 1773, he added an introduction about linguistic theory. The most elaborate, and third, version was published in German in Vienna in $1774{ }^{6}$

Reading Kalmár's oeuvre, one can quickly identify some constant features and recurrent claims, such as, first, the insistence on the necessity of interpreting the perceived world, second, using figurative language as a unique tool of interpretation. It is quite striking that even though Kalmár was quite familiar with both the preceding and the contemporary universal language theories (including Bishop John Wilkins' famous work), he disagreed with their theoretical basis. His aim was not creating a unique general language, but showing the common features in various, possibly all, languages, and signify them with specific characters and symbols. What made his plan unique was that he did not attach one specific meaning to his signs, because, according to his insistence on the extreme heterogeneity of language, meaning for him only existed in context. ${ }^{7}$

Consequently, he did not consider figurality an error occasionally made by using language, but a necessary basis for all speech acts. As for cognition, he took for granted both the figurative nature and the indispensability of language. Theories of language, if based on an Aristotelian epistemology, took metaphor as a way of transferring a word from one meaning to another on the basis of similarity. This inevitably results in inaccurate language usage, even if it should be avoided in theoretical language reflecting the world. However, Kalmár shared Lambert's view that the figural usage is one of the most important means of language extension in semiotics: metaphorical meanings may become independent, and only context will clearly decide the actual meaning. The historical change the meaning of a word goes through also confirms this. (I must note that although independent metaphorical meaning is still based on the comparison of characteristics, this fact is not relevant for now.) Furthermore, Lambert - quite surprisingly - considers the metaphorical meaning of a word a natural sign precisely because - unlike the concept of linguistic signs in Leibniz's Wechselzettel theory - he sees well-applied metaphors related to the replaced notion, if not the represented entity itself.

In general, Kalmár's language theory had its origins in 17th-18th century epistemology and the ideology of continental pietism. In what follows, I will use Leibniz's theory of cognitio symbolica as a guiding principle to integrate Kalmár's theory into the corresponding philosophical tradition and to outline a parallel theological tradition. Leaving his early works out of consideration and analysing only his universal language plan would prove insufficient for getting a comprehensive picture of his language theory in general. ${ }^{8}$

The work in Kalmár's oeuvre that attracted the most attention in Hungarian literary history was his Prodromus idiomatis Scythico-Mogorico-Chuno-Avarici: sive adparatus criticus ad linguam Hungaricam, published in Pressburg/Bra- 
tislava in 1770. It consists of two parts: the first is a Hungarian grammar in Latin, with the first Hungarian prosody on metrical Hungarian versification attached. The second part is a poem in Hungarian consisting of 5000 hexameters under the title: Valóságos magyar ABC (An English translation could be: True alphabets of the world in Hungarian language). The Latin title given by Kalmár varies a bit: Thesaurus Hungaricus. His own definition of its genre: poema universale.

In the poem he elaborates the following problem: even if language may be able to express each and every idea and thought, this language could not be used (in an adequate way) until we possess a real and genuine knowledge of the world. Due to mankind's original sin, cognitio clara as defined by Leibniz is not feasible. Nevertheless, Kalmár claims that language is still the only source of cognition, because all existing languages bear traces of the wisdom from the period preceding the original sin. The most essential evidence for this is the Bible.

The same ideas also appear in the introduction on linguistic theory Kalmár attached to the German translation of his universal language plan.

1.) Erhellet aus dem schon gesagten, dass keine Sprache sey, die nicht etwas philosophie in sich enthielte; und in diesem weitesten verstande ist jede Sprache philosophisch. ${ }^{9}$

Using basic epistemological terms Kalmár interprets words as Wechselzettelsimilarly to Leibniz Unvorgreifflichen Gedanken:

So wie die bilder der Dinge, durch die Kunst der Maler aufgestellt, die dinge selbst ausdrücken; eben so sind begriffe der dinge schilderungen der dinge selbsten, wenn sie mit gewissen wörtern, als zeichen ausgedrückt werden. ${ }^{10}$

Consequently, Kalmár also had to deal with the concept of linguistic heterogeneity. He had to provide an explanation to the generally experienced phenomenon that two speakers can actually understand each other. This is how he puts it:

...jeder Besitzer ["owner of language", which he also uses as "language user"] seine eigene nur ihm vertraute, und folglich von den übrigen verschiedene Sprache schreibet und redet. In dieser metphysischen betrachtung redet man anders mit GOTT, anders mit dem regierenden Fürsten, anders mit dessen Erben [...]. Anders spricht der Bräutigam mit der Braut, anders der Mann mit dem Eheweibe, und wieder anders, wenn sie beyde tugendhaft, oder ein theil, oder beyde verderbt sind. Gebe man zu, dass die in allen diesen besonderen fällen gebrauchten Worte und Redensarten einer Sprache physisch die nämlichen sind. Wer dieses auch von ihrer metaphysischen beschaffenheit und ihrem nachdruck behaupten wollte, würde sehr weit von der wahrheit abgehn. ${ }^{11}$ 
Kalmár claims that despite the homogeneity in language, each speaker has his own usage of the language, if a sign for an idea, a word is explained in a thorough way, possibly with more than one word, then the language users will be able to understand each other.

Consequently, real understanding depends exclusively on the specific linguistic situation. This accounts for the most significant attribute of his universal language plan: in contrast with taxonomic systems, he uses a set of no more than 400 characters, because he believes that the proper use of these characters in various situations would allow expressing any possible idea. This is the reason why he does not refer to his language plan as an "invented language", for he thinks that its core to which he gives birth can be found in all languages, and as such, it is directly available to everyone capable of speaking any language. Therefore, he firmly distinguishes between his own plan and the preceding ones:

\begin{abstract}
...was ich schon gesagt habe, dass jene Philosophische oder Allgemeine Sprache, metaphysisch betrachtet, immer vorhanden gewesen sey, ehe noch ein erhabner Lambert und die scharfsichtigen Weisen des Cartes und Wolf auf ihre Art davon dachten; ehe der verbreitete und dennoch so gründliche Genius eines Leibnitzes darüber zu rathe gieng, und seine Vorschläge in einem Beyspiele, nach seiner Art daran machte; ehe sie noch Kircher, Dahlgarne, Becher, und andre, jeder auf seine Art, und Solbrig mit den 12000 Zusammensetzungen der Zahlziffern versuchte... ${ }^{12}$
\end{abstract}

What also follows is that the language he rediscovered may only exist in and as writing, however, its written nature does not correspond to that of other languages, as it is more of a thought-language, that is, an immediate representation of conceptual contents and ideas. And this is where the early Hutchinsonian debate on the "scripture-Meaning of the words in Elohim and Berith" joins in. (The debate in which Kalmár, as I have mentioned, was also involved during his Oxford and London years, two decades before the publication of his universal language plans. ${ }^{13}$ I will not outline the Hutchinsonian movement now, but touch only some points of the discussion relevant to Kalmár's theory of language. ${ }^{14}$

Consider the following points made by the Hutchinsonians: according to them, Hebrew is not only the primary language of divine revelation, but also the language which brought about a fellowship between the Trinity even before the Genesis. Therefore, "real Hebrew" can exclusively be found in the unpunctuated text of the Old Testament; the punctuated version written by "apostate Jews" is not faithful to the original text. Consequently, the Hebrew Scriptures as restored by the Hutchinsonians provide the ultimate source of all human knowledge. This supposition is refuted in an effective way by the anti-Hutchinsonian Arthur Bedford, already in the first phase of the debate: 
I will note say (as the Author doth) that they [wiz: Hebrew Scriptures] are Repositories of all natural Knowledge, there are many Propositions in Euclid, which I cannot demonstrate from thence, and many Particulars in experimental Philosophy both Terrestrial and Celestial, which they were never intended to give us any Account of. ${ }^{15}$

According to the Hutchinsonians, no language can amount to the perfection of signification in Hebrew, therefore almost all their writings are characterized by their hostility towards translation. ${ }^{16}$

The idea of the impossibility of translation also occurred in the second phase of the Hutchinsonian debates. Julius Bate claimed - as a logical outcome of John Locke's theory of language - that even in the translation of the Old Testament what we comprehend are not the words of God, but those of the translator. ${ }^{17}$ David Aboab also raises this issue: May I declare that the word God is not merely a translation of Deus, or the latter that of theosz...? In Aboab's view this can only be approved if it can be verified that the English word is of the same meaning as the Latin, and the Latin as the Greek. In the defense of translation it can be claimed that in English the word God is the general signifier of the Supreme Being, just like the Latin Deus, the Greek theosz, the Hebrew Elohim, however, they all differ in their meanings.

Kalmár simply defies this theory of intranslatability. The basis of his refusal is a peculiar interpretation of the arbitrariness of the linguistic sign, a fact he himself nevertheless acknowledged, which he elaborated in his polemical essay against Aboab. First he strictly reduces the arbitrariness of the linguistic sign to arbitrary denomination:

By arbitrary denomination I mean, that it depends wholly on one's Will or Choice to give to such a thing, or to such an action, such $a$ Name, which either conveys with itself any Idea of any property, or any circumstance, to be found in, or, about that very thing or action; or none at all.

Kalmár gives the example that if one happens to see a gold mountain yet unknown, and gives it the name of $A b$. But it would be equally arbitrary if he designated it on the basis of the ideas of its composing parts. ${ }^{18}$ Therefore, quite significantly, arbitrariness does not imply the impossibility of any relation between signifier and signified. At first it might seem that in the case of ultimate arbitrariness, unrelated to ideas and circumstances, relations emerge only between things and words, and not between ideas and words. As a matter of fact, Kalmár's thesis does not include this argument, however, it can be deduced from it. Nevertheless his pamphlet against Bate excludes this possibility. In the immediate context of his statement he uses the word concretum to designate the thing/object, and 
abstractum to designate idea: "the concretum cannot be conceived without implying, or be declared but by, its abstractum." ${ }^{, 19}$ My interpretations are as follows: 1) the thing/object cannot be perceived without involving its idea; 2) statements about a thing/object can only be made through its idea. This claim is worth further elaboration, however at the present I focus on the interpretation according to which the level of ideas is at work even during completely arbitrary designations, although according to Kalmár it fulfills only one condition. He does not write about the arbitrariness of the idea, but the concept of expression he introduced in his pamphlet against Bate, dealing with the translatability of the Bible and the utterances of Jesus, might be connected to this problem. According to this locus, an expression remains the same even if uttered in different languages. Perhaps the meaning of the Hungarian expression kimondó, which Kalmár introduced in the 1770 s in his Magyar Merkúrius, is also to be found here. ${ }^{20}$

Nevertheless, if we take this idea further, what we see is a unique epistemological-linguistic experiment that must not be smiled at. Let us take a language, Hebrew this time, and all the past, present and future writings and revelations in that language as one set. Now let us define within this set a sub-set with clear limits. What makes this a bit easier is that this sub-set - Old Testament, or the Hebrew Scriptures as Hutchinsonians called it - is written and completed. Now try to conceive the inconceivable: this sub-set has nothing to do with the set. Words of the sub-set can be (explained and) interpreted only within the sub-set. This is how to grab a meta-language, which - thanks to its divine origin - is completely suitable for interpreting the world. If we add that in this language - according to the Hutchinsonians - each root has only one specific meaning which is kept even in the derivations, then we have the 17th-18th century linguists' great dream come true: the perfect universal language.

In the documents of the debate one can see that, quite naturally, most of the anti-Hutchinsonian arguments were taken from Hebrew philology. This was the very reason why the opposing parties failed to have a real debate. Kalmár seems to be the only participant who tried to analyse the meaning of words irrespectively of Hebrew philology. Even he was ready to admit that words never have a meaning, only the so-called expressions. As he puts it in his work "Mr. Bate's Answer to Dr. Sharp's two Dissertations answered: being Vindication of the Etymology and Scripture-Meaning of Elohim and Berith":

It doth not signify, what Language Christ talked in, whether Hebrew, or Syriac or Greek etc.: it is enough for our purpose that he hath used the same Expression. Cannot one use the same expression in English. or Irish. or Welsh. or French. or Dutch etc? ${ }^{21}$

This argument clearly is an antecedent of Kalmár's later universal language theory of 400 signs (roots) in figural usage being sufficient for an educated person 
to read texts written in the universal language in the same expression. The origins of the linguistic framework of Kalmár's plan for a universal language are to be found somewhere here, in the Hutchinsonian debate, a debate basically about two particular Hebrew words.

This correspondence could be further stressed by the fact the first publication, a proposal, in which Kalmár had brought forward his universal language, followed directly his pamphlets and appeared while he was still in London in 1753 under the title: PROPOSALS For printing by SUBSCRIPTION, AN UNIVERSAL $L A N G U A G E$. In that text he gives the following explanation:

THIS LANGUAGE is adapted not only to those of all Nations (even to that of the Chinese, in some part, that can read and write at all); but also to all Arts and Sciences. It is, upon the whole, promising so much that no sooner one looks over it, but he finds in himself an Inclination and Readiness to, and, of course, a great Pleasure in, the learning to fit. ... And as for the LANGUAGE itself, there is very little in it that was drawn after Bishop Wilkin's Plan. ${ }^{22}$

As this argument proves, Kalmár's views are radically different from John Wilkins' tautological system. And not only in the comprehensive theory he published somewhat two decades later, but already in his early contribution to the Hutchinsonian debate as well.

\section{Notes}

1 This paper is an edited version of my lecture held on the workshop entitled Encyclopaedism, Pansophia, and Universal Communication at the Central European University, Budapest, April 15, 2010.

2 Eco, Umberto: The Search for the Perfect Language. Oxford: Blackwell 1995 (The making of Europe), 302.

3 In the following I will summarize the results of my book: Prodromus. Kalmár György (1726-?) világáról [On Kalmár György's world]. Budapest: Argumentum 2008 (Irodalomtörténeti füzetek 164). A very good introduction to his life with before unpublished sources: Szelestei, N. László (ed.): Kalmár György, , a magyar nyelv szerelmese”. Piliscsaba: Pázmány Péter Katolikus Egyetem 2000 (Pázmány Irodalmi Múhely. Források).

4 Lambert, J. Heinrich: Briefwechsel, II, ed. by Bernoulli, Johann. Berlin 1781-1782, 67-70, 71-73. These letters are republished in my book Prodromus... 2008.

5 Even Johann Georg Hamann mentioned him and his works in a letter written to Johann Gotthelf Lindner in 1761: "Hier hat sich einige Zeit eine gelehrte Seltenheit aufgehalten, die von einigen unter dem Namen eines ägyptischen Studenten bewundert worden..." Ziesemer, Walther - Henkel, Arthur (eds.): Johann Georg Hamann: Briefwechsel, II, 1760-1769. Insel-Verlag 1956, 98-99.

6 Praecepta grammatica atque specimina linguae philosophicae sive universalis ad omne vitae genus accommodatae. Berolini et Lipsiae 1772; Precetti di grammatica per la lingua 
philosophica.... Roma 1773; Grammaticalischen Regeln zur philosophischen oder allgemeinen Sprache.... Wien 1774.

7 On Kalmár's theory of language and on the origins of them, see: Hegedüs, Béla: Kalmár György nyelvelméletéről, in: Devescovi, Balázs - Szilágyi, Márton - Vaderna, Gábor (eds.): Kolligátum. Tanulmányok a hetvenéves Bíró Ferenc tiszteletére. Budapest: Ráció 2007, $167-176$

8 Kalmár's most important, mentioned sources are: Lambert, Johann Heinrich: Neues Organon. Berlin: Akademie 1990 [1760]; Leibniz, Gottfried Wilhelm: Betrachtungen über die Erkenntnis, die Wahrheit und die Ideen [Meditationes de cognitione, veritate, et ideis]. Stuttgart: Reclam 1995 [1684]; Leibniz, Gottfried Wilhelm: Unvorgreifliche Gedanken.... Stuttgart: Reclam 1995 [1717].

9 Kalmár 1774, iv.

10 Kalmár, 1774, vi.

11 Kalmár, 1774, xv-xvi.

12 Kalmár 1774, v.

13 The three pamphlets he published connected to the debate in the early 1750s: A short reply to Mr Holloway's few remarks on Dr Sharp's Dissertation on the Words Elohim and Berith, London 1751, Mr. Bate's answer to Dr. Sharp's two dissertations answered: Being a vindication of the etymology and Scripture-Meaning of Elohim and Berith, London 1751; Censurer censured: or a defence of Dr Sharp's two dissertations on the Hebrew words Elohim and Berith. Being a reply to Mr Aboab 's remarks, London 1751.

14 See my paper on this topic: Hegedüs, Béla: John Locke, a hutchinsoniánusok és Kalmár György a nyelvről. Egy 18. századi brit vita nyelvelméleti tanulságai, in: Hites, Sándor Török, Zsuzsa (eds.): Épitész a köfejtöben/Architect in the Quarry. Tanulmányok Dávidházi Péter hatvanadik születésnapjára/Studies Presented to Péter Dávidházi On His Sixtieth Birthday. Budapest: rec.iti 2010, 358-360. [The whole content of the book is available: http://rec.iti.mta.hu/rec.iti/Members/szerk/architect]. Important introductions to the history of the Hutchinsonian movement: Kuhn, Albert J.: Glory or Gravity: Hutchinson vs. Newton, in Journal of the History of Ideas, 1961/3, 303-322; Leighton, C. D. A.: "Knowledge of divine things": A study of Hutchinsonianism, in: History of European Ideas 2000, 159-175; Gürses, Derya: The Hutchinsonian defence of an Old Testament Trinitarian Christianity: The controversy over Elahim, 1735-1773, in: History of European Ideas, 2003, 393-409; Gürses, Derya: Academic Hutchinsonians and their quest for relevance, 1734-1790, in: History of European Ideas, 2005, 408-427.

15 Bedford, Arthur: Observations on a sermon preach'd before the Corporation of Bristol. London 1736, 8 .

16 E. g.: [Julius Bate], The examiner examined, or the examination of the remarks upon, and Mr. Catcott's answer to, The observation upon his sermon considered..., 1739, 38.

17 Julius Bate, The Scripture meaning of Aleim and Berith justified against the exceptions of Dr. Sharp..., 1751, 110.

18 George Kalmár, Censurer Censured: or a Defence of Dr Sharp's Two Dissertations on the Hebrew Words Elohim and Berith. Being a Reply to Mr Aboab 's Remarks, 1751, 29, footnote.

19 George Kalmár, Mr. Bate's Answer to Dr. Sharp's Two Dissertations Answered: Being a Vindication of the Etymology and Scripture-Meaning of Elohim and Berith, 1751, 68.

20 Kalmár György, Magyar Merkúrius = Kalmár György, ,, a magyar nyelv szerelmese”, s. a. r. és bev. Szelestei N. László, Piliscsaba, PPKE, Bölcsészettudományi Kar, 2000 (Pázmány Irodalmi Mühely. Források, 2), 147-156.

21 Kalmár, George: Mr. Bate's answer to Dr. Sharp's two dissertations answered..., 1751, 63.

22 The two-pages advertisement is republished in my book: Prodromus..., 2008, 120-122. 